\title{
Hubungan Antara Iklim Organisasi Dengan Work Family Balance Pada Guru Wanita Bersertifikasi Yang Sudah Berkeluarga Di Smp N 2 Sawahlunto
}

\author{
Diana Trie Yunisa, Herio Rizki Dewinda \\ Fakultas Psikologi, Universitas Putra Indonesia "YPTK” Padang, Indonesia \\ Email: yunisadiana007@gmail.com, hrdewinda@gmail.com
}

\begin{abstract}
The research purpose to determine the relationship between organizational climate and work family balance in certified teachers in married women in SMP N 2 Sawahlunto. The independent variable in this research is organizational climate and the dependent variable is work family balance. The sampling tecnique in this research use saturated sampling technique. The sample in this study were 33 certified teacher in married women in SMP N 2 Sawahlunto. The validity and reliability test in this study uses the alpha cronbach technique. The result of the validity coefficien on the scale of organizational climate moves from $r_{i x}=0.326$ to $r_{i x}=0.742$ with a reliability coefficient of $\alpha=0.915$ while on the work family balance move from $r_{i x}$ $=0.304$ to $r_{i x}=0.726$ with a reliability coefficient of $\alpha=0.904$. Based on data analysis, a correlation value of 0.671 that is with a significance level of 0.000 , which means the hypothesis is accepted. This shows that there is a significant relationship organizational climate and work family balance in certified teachers in married women in SMP N 2 Sawahlunto. The effective contribution of the organizational climate variable to work family balance $45 \%$
\end{abstract}

Keywords: : organizational climate, work family balance, teachers.

\begin{abstract}
Abstrak
Penelitian ini bertujuan untuk mengetahui hubungan antara iklim organisasi dengan work family balance pada guru wanita bersertifikasi yang sudah berkeluarga di SMP N 2 Sawahlunto.Variabel bebas dalam penelitian ini adalah Iklim organisasi dan variabel terikat adalah work family balance. Alat ukur yang digunakan dalam penelitian ini adalah skala iklim organisasi dan skala work family balance. Teknik pengambilan sampel dalam penelitian ini menggunakan teknik sampel jenuh. Sampel dalam penelitian ini berjumlah 33 orang guru wanita tersertifikasi yang sudah berkeluarga di SMP N 2 Sawahlunto.Uji validitas dan reliabilitas pada penelitian ini menggunakan teknik Alpha Cronbach. Hasil koefisien validitas pada skala iklim organisasi berkisar dari 0,326 sampai dengan 0,742 dengan koefisien reliabilitas sebesar $a=0,915$. Sedangkan hasil koefisien validitas pada skala work family balance antara 0,304 sampai dengan 0,726 dengan koefisien reliabilitas sebesar $a=0,904$. Hasil uji hipotesis menunjukkan besarnya koefisien korelasi sebesar 0,671 dengan taraf sifnifikan $p=0,000$ yang berarti hipotesis diterima. Hal ini menunjukkan adanyan hubungan yang signifikan antara iklim organisasi dengan work family balance pada guru wanita bersertifikasi yang sudah berkeluarga di SMP N 2 Sawahlunto. Adapun sumbangan efektif dari variabel iklim organisasi terhadap work family balance sebesar $45 \%$.
\end{abstract}

Kata Kunci: iklim organisasi, work family balance, guru

\section{Pendahuluan}

Pada era modern sekarang ini, banyak dijumpai di lapangan jenis pekerjaan atau profesi yang biasanya dikerjakan pria kini mulai dikerjakan oleh wanita. Wanita kini tidak lagi dianggap sebagai sosok yang hanya bertugas mengurus anak, suami dan rumah tangga saja. Perubahan pandangan terhadap peran wanita yang semula hanya bertugas mengurus rumah tangga terjadi karena adanya anggapan bahwa sekarang karir dan pekerjaan bagi ibu rumah tangga saat ini di pandang bukan lagi sebagai pilihan, tetapi sudah merupakan aktualisasi diri (Ananda, 2013). Keputusan wanita yang telah menikah untuk bekerja menjadikan wanita memiliki tanggung jawab dengan pemenuhan peran dalam pekerjaan dan keluarga. Mederee mengatakan bahwa wanita memiliki rasa tanggung jawab terhdap tugas-tugas rumah tanga yang lebih besar dibandingkan pria (dalamAyuningtyas \& Septarini, 2013). Menurut Dewi (dalam Maulana, 2017) bagi kaum wanita yang sudah berkeluarga, pekerjaan dan kehidupan keluarga merupakan realisme dwi tunggal yang tidak dapat dipisahkan satu dengan yang lainnya.Individu mau tidak mau harus mengupayakan perimbangan untuk dapat menyesuaikan antara dua kepentingan tersebut. Menurut Triwahyuni (dalam Novenia \& Ika, 2017) guru dipandang sebagai profesi yang cocok untuk wanita karena adanya sifat alamiah dasar guru yaitu membimbing, mendidik

Diterima Redaksi : 13-02-2020 | Selesai Revisi : 4-05-2020 | Diterbitkan Online : 1-06-2020 
dan mengarahkan. Menurut Weiss (dalam Bulmer, 2015) guru wanita yang sudah berkeluarga harus bisa mengatasi dan bertanggung jawab untuk dapat menyelesaikan tugas-tugas pekerjaannya begitu juga dengan tugas-tugasnya di dalam sebuah rumah tangga. Menurut Greenhose,dkk (dalam Novenia \& Ika, 2017) mengatakan work family balance adalah sejauh mana individu terlibat dan puas dengan peran dalam urusan pekerjaan dan keluarga. Individu yang tidak memiliki waktu untuk bersantai dan memulihkan kembali fisiknya, kemampuan dalam menyelesaikan pekerjaan akan menurun. Tanpa adanya keseimbangan antara pekerjaan dan keluarga, seseorang tidak dapat menikmati hidupnya dan akan merasa terbebani. Kesulitan untuk bertemu dengan teman, keluarga dan pasangan (Meenakshi, 2013). Guest menyampaikan bahwa work family balance berhubungan dengan faktor-faktor diantaranya dukungan organisasi, dukungan keluarga, kepribadian, orientasi kerja, jenjang karir dan iklim organisasi (dalam Ayuningtyas \& Septarini, 2013). Berdasarkan penelitian yang dilakukan oleh Greenhause, Ziegert \& Allen (2012) bahwa seorang lebih mudah mencapai work family balance jika bekerja dilingkungan organisasi yang suportif terhadap keluarganya. Iklim organisasi adalah salah satu hal penting untuk diperhatikan dalam pemenuhannya, sebab terdapat aspek yang signifikan yang mempengaruhi keadaan individu, Lussier (dalam Ardiansyah, 2017).

Menurut Tagiuri \& Litwin (dalam Ardiansyah, 2017) iklim organisasi adalah suatu keadaan yang ada di lingkungan organisasi yang tercipta dalam suatu organisasi yang menggambarkan keadaan atau kondisi kerja di dalam organisasi. Iklim organisasi merupakan keadaan lingkungan organisasi yang dirasakan oleh pekerja yang mengarah pada aspek-aspek seperti keamanan psikologis dan kebermaknaan psikologis lingkungan kerja. Iklim organisasi yang mempengaruhi tinggi rendahnya work family balance dimulai dari peraturan kerja yang kaku, beban kerja yang berta, waktu kerja serta ketidak nyamanan psikologis. Situasi demikian akan membuat ibu menjadi amat lelah, sementara kehadirannya dinantikan oleh keluarga dirumah. Kelelahan fisik dan psikis itulah yang membuat sensitif dan emosional, baik terhadap anak-anak maupun terhadap suaminya. Keadaan ini biasanya makin intens kala situasi dirumah tidak mendukung, suami dan anak-anak kurang bisa berkerjasama untuk bergantian membantu meringankan pekerjaan rumah tangga, Rini (dalam Vitarini, 2009). Ketika terdapat hubungan yang positif atau membangun bisa dipastikan seseorang merasa nyaman untuk bekerja di lingkungan kerja tersebut. Perlu diketahui bahwa setiap organisasi akan memiliki iklim organisasi yang berbeda. Adanya iklim organisasi dapat mempengaruhi seorang lebih mudah mencapai work family balance jika bekerja di lingkungan organisasi yang suportif terhadap keluarganya sesuai dengan penelitian Greenhuse, Ziegert \& Allen (2012). Iklim organisasi yang dimaksud seperti ketika seseorang memiliki resiko kerja yang sedikit, memiliki teman baik maupun peduli dan konflik kerja yang sedikit maka keseimbangan bekerja dan berkeluarga akan terjaga dengan baik begitupun sebaliknya apabila seseorang memiliki resiko kerja yang berat, teman-teman yang kurang mendukung, konflik kerja yang banyak maka keseimbangan bekerja dan berkeluarga tidak akan tercapai. Sehingga apabila memiliki iklim organisasi yang baik maka otomatis dapat memilik work family balance yang baik pula (Ayuningtyas \& Septarini, 2013). Berdasarkan hasil wawancara dengan guru wanita bersertifikasi yang sudah berkeluarga di SMP N 2 Sawahlunto adanya ketidakseimbangan pekerjaan dan keluarga terdapat kondisi guru sulit melibatkan peran dalam keluarga karena waktu untuk berkumpul bersama menjadi semakin sedikit ibu perlu berada disisi anak-anak dan suami, anak perlu dibimbing, ditemani ataupun diarahkan, anak ingin ibu menyisihkan waktu untuknya ataupun suami yang perlu kehadiran istrinya, begitupun perannya dalam mengatur urusan rumah tangga seperti membersihkan rumah, memasak dan banyak hal lainnya yang harus dikerjakan. Profesi guru wajib datang enam hari kerja, minimal 8 jam berada di sekolah harus datang tepat waktu dari pukul 7 pagi hingga jam 3 sore, jika terlambat ataupun tidak hadir berurusan langsung pada bendahara dengan sanksi yang diterima berdasarkan persentase kesalahan.

Meskipun 8 jam berada disekolah, pekerjaan guru masih belum tuntas, tuntan guru yang mengambil sertifikasi wajib mengisi jam mengajar minimal sebanyak 24 jam. Sehingga sulit bagi guru untuk mendapatkan peluang mengurus dan mengerjakan hal lain.Sebab waktu guru banyak terpakai untuk bekerja disekolah dari pada perannya mengurus rumah tangga. Ditambah aturan baru yang membuat guru kesulitan jika mengambil izin, karena jika guru tersebut terlambat finger print ataupun tidak masuk kerja akan mendapatkan sanksi dipotongnya tunjangan daerah guru tersebut berdasarkan persentase kesalahan yang ditangani langsung oleh bendahara. Terdapat salah satu peraturan baru dari dinas pendidikan Kota Sawahlunto mengenai izin, guru hanya diperbolehkan untuk izin alasan penting, yaitu jika orang tua, mertua, suami dan anak sakit, diluar itu guru terkena sanksi harus siap 
menerima resiko dengan dipotongnya tunjangan sertifikasi, sekalipun guru tersebut hanya izin satu hari saja di tanggal akhir bulan guru siap mendapatkan sanksi tidak menerima tunjangan sertifikasi selama satu bulan.

\subsection{Work Family Balance}

Menurut Greenhause (dalam Novenia \& Ika, 2017) work family balance adalah sejauh mana individu terlibat dan puas dengan peran dalam urusan pekerjaan dan keluarga. Kalliath \& Brought (dalam Novenia \& Ika, 2017) work family balance digunakan untuk seorang pekerja yang berstatus sebagai orang tua atau orang yang telah menikah dan menginginkan keseimbangan dalam pekerjaan maupun keluarganya. Keseimbangan kerja keluarga adalah suatu keadaan individu merasa efektif dan merasakan kepuasan dalam peran keluarga dan kerja yang cocok dengan prioritas skala kehidupannya, Voydanoff (dalam Handayani,dkk, 2018). Frone (dalam Ayuningtyas \& Septarini, 2013) mengatakan bahwa work family balance digambarkan oleh sedikitnya masalah yang timbul karena menjalani berbagai peran dan mendapatkan keuntungan dalam menjalani peran tersebut. Greenhaus,dkk (dalam Wijayanto \& Nailul, 2018) mengatakan manfaat yang didapatkan dari tercapainya work family balance bagi individu yaitu ketika individu tersebut bisa meningkatkan kualitas hidupnya, karena keterlibatan individu tersebut ke dalam beberapa peran dapat melindungi individu dari efek negatif salah satu peran dan mampu tanggap dalam menghadapi tuntutan peran.

\subsection{Komponen Work Family Balance}

Menurut Greenhause,dkk (dalam Ayuningtyas \& Septarini, 2013) ada tiga komponen yaitu : (a). Keseimbangan waktu (Time balance) Merupakan keseimbangan waktu dalam pekerjaan dengan keluarga. Work family balance bisa berjalan dengan baik apabila seorang bisa membagi waktu yang seimbang antara waktu untuk bekerja dan waktu untuk keluarga, sehingga masing-masing peran dapat dijalankan sesuai dengan semestinya (b) Keseimbangan Keterlibatan (Involvement balance) Keterlibatan psikologis dalam pekerjaan dan keluarga. Work family balance bisa berjalan dengan baik apabila seseorang harus memiliki keterlibatan secara psikologis dan komitmen terhadap peran dalam pekerjaan maupun peran dalam keluarga (c) Keseimbangan Kepuasan (Satisfaction balance) Kepuasan yang individu yang seimbang dalam menjalankan peran dalam pekerjaan maupun peran di dalam keluarga.

\subsection{Iklim Organisasi}

Menurut Taguiri dan Litwin (dalam Wirawan, 2008) iklim organisasi merupakan kualitas lingkungan internal organisasi yang secara relatif terus berlangsung, dialami oleh anggota organisasi mempengaruhi perilaku mereka dan dapat dilukiskan dalam pengertian satu set karakteristik atau sifat organisasi, Forehand dan Gilmers (dalam Prihatsanti \& Kartika, 2010) menyatakan bahwa iklim organisasi adalah serangkaian deskripsi dari karakteristik organisasi yang bertahan dalam jangka waktu lama. Karakteristik ini membedakan satu organisasi dari organisasi lain dan mempengaruhi perilaku orang-orang yang termasuk dalam organisasi tersebut.

\subsection{Dimensi Iklim Organisasi}

Iklim organisasi dari sebuah organisasi memiliki beberapa dimensi yang dapat mempengaruhi suatu kondisi utuh sehingga dapat dirasakan oleh anggota organisasi, berikut ini dimensi ilim organisasi menurut Stringer (dalam Wirawan, 2016) yaitu : (a) Struktur, merefleksikan perasaan diorganisasi secara baik dan mempunyai peran dan tanggung jawab yang jelas dalam lingkungan organisasi (b)Tanggung Jawab, merefleksikan perasaan bahwa mereka menjadi "bos diri sendiri" dan tidak memerlukan keputusannya dilegitimasi oleh anggota organisasi (c)Penghargaan, mengindikasikan anggota organisasi merasa dihargai jika mereka dapat menyelesaikan tugas secara baik (d) Standar,suatu organisasi mengukur perasaan tekanan untuk meningkatkan kinerja dan derajat kebanggaan yang dimiliki oleh anggota organisasi dalam melakukan pekerjaan dengan baik (e) Dukungan,merefleksikan perasaan percaya dan saling mendukung yang terus berlangsung di antara anggota kelompok kerja (f) Komitmen,merefleksikan perasaan kebanggan anggota organisasi terhadap organisasi capaian tujuan organisasinya. Level rendah komitmen merasa apatis terhadap organisasi dan tujuannya. 


\section{Metode Penelitian}

Jenis penelitian ini adalah kuantitatif korelasional dengan variabel penelitian Menurut Sugiyono (2016) variabel independent iklim organisasi (Y) dan variabel dependent (X) work family balance. Populasi dalam penelitian adalah guru wanita bersertifikasi yang sudah berkeluarga di SMP N 2 Sawahlunto dengan total 33 orang guru. Teknik nonprobability sampling yang digunakan adalah sampel jenuh yaitu teknik penentuan sampel bila semua anggota populasi digunakan sebagai sampel. Hal ini sering dilakukan bila populasi relatif kecil, penelitian yang ingin membuat generalisasi dengan kesalahan yang sangat kecil (Sugiyono, 2016). Bentuk skala yang digunakan untuk mengukur Iklim organisasi dan work family balance adalah model likert yang telah dimodifikasi menjadi empat alternatif jawaban dan item-item dalam skala ini dikelompokkan dalam item favourable dan unfavourable. Bentuk skala yang digunakan untuk mengukur iklim organisasi dan work family balance memiliki format dengan empat alternatif jawaban. Menurut Sugiyono (2016) skala Likert digunakan untuk mengukur sikap, pendapat dan persepsi seseorang atau sekelompok orang tentang fenomena sosial. Format respon jawaban skala iklim organisasi dan skala work family balance berdasarkan empat pilihan jawaban, yaitu SS (Sangat Setuju), S (Setuju), TS (tidak Setuju), dan STS (Sangat Tidak Setuju).

Skala penelitian akan melewati berbagai tahap analisis yaitu uji normalitas digunakan untuk mengetahui apakah populasi data terdistribusi normal atau tidak. Uji normalitas menggunakan uji kolmogorov-Smirnov. Uji linearitas bertujuan untuk mengetahui apakah dua variabel mempunyai hubungan yang linear atau tidak. Dua variabel dikatakan mempunyai hubungan yang linear bila signifikasi (linearty) kurang dari 0,05. Selain itu dilakukan uji Validitas, sejauh mana ketepatan dan kecermatan suatu alat ukur dalam melakukan fungsi ukurnya (Azwar, 2015). Suatu item dapat dianggap memiliki daya diskriminasi yang memuaskan jika berkorelasi signifikan terhadap skor total atau jika melakukan penilaian langsung terhadap koefisien korelasi bisa digunakan batas nilai berkriteria $r_{x y} \geq 0,3$ (Priyatno, 2018). Data skala dikatakan memiliki daya beda tinggi jika koefisien korelasi lebih besar atau sama dengan $0,3\left(r_{x y} \geq 0,3\right)$ dan sebaliknya item skala dikatakan gugur jika koefisien korelasi lebih kecil dari $0,3\left(\mathrm{r}_{\mathrm{xy}} \geq 0,3\right)$.

\section{Hasil dan Pembahasan}

Peneliti menyebarkan 33 skala iklim organisasi dengan work family balance, serta meminta kesediaan guru wanita tersertifikasi yang sudah berkeluarga untuk mengisi skala kemudian menjelaskan cara pengisian skala dengan memberikan contoh. Setelah skala dibagikan dan selesai di isi oleh guru wanita tersertifikasi yang sudah berkeluarga, jumlah skala yang kembali kepada peneliti sebanyak 33 skala dan sesuai dengan jumlah sampel penelitian.

\subsection{Hasil}

Koefisien Validitas skala Iklim Organisasi dengan nilai corrected item-total correlation berkisar antara 0,326 sampai dengan 0,742, dengan reabilitas 0,915, validitas skala Work Family Balance dengan nilai corrected item-total correlation berkisar antara 0,304 sampai dengan 0,726, dengan reabilitas 0,904. Uji normalitas dalam penelitian ini menggunakan uji Kolmogorov-Smirnov. Priyatno (2018) menyatakan bahwa data yang dinyatakan berdistribusi normal jika signifikansi (p) lebih besar dari 0,05. Berdasarkan hasil pengolahan data dengan menggunakan program IBM SPSS 21.0, Maka diperoleh hasil sebagai berikut:

Tabel 1. Uji Normalitas Skala Iklim Organisasi dengan Work Family Balance

\begin{tabular}{ccccc}
\hline Variabel & N & KSZ & P & Sebaran \\
\hline Iklim Organisasi & 33 & 0,906 & 0,385 & Normal \\
Work Family Balance & 33 & 1,024 & 0,246 & Normal \\
\hline
\end{tabular}

Nilai signifikansi pada skala Iklim Organisasi sebesar $\mathrm{p}=0,385$ dengan KSZ $=0,906$ hasil tersebut menunjukan bahwa nilai $\mathrm{p}>0,05$, artinya sebaran skala Iklim Organisasi terdistribusi secara normal, sedangkan untuk skala Work Family Balance diperoleh nilai signifikansi sebesar $\mathrm{p}=0,246$ dengan 
$\mathrm{KSZ}=1,024$ hasil tersebut menunjukan bahwa nilai $\mathrm{p}>0,05$, artinya sebaran terdistribusi secara normal. Selanjutnya uji linearitas dapat dilihat pada tabel 2 berikut:

Tabel 2. Uji Linieritas Iklim Organisasi dengan Work Family Balance

\begin{tabular}{ccccc}
\hline $\mathbf{N}$ & Df & Mean Square & F & Sig \\
\hline 33 & 1 & 1799,597 & 51,746 & 0,000 \\
\hline
\end{tabular}

Berdasarkan tabel diatas, diperoleh nilai $\mathrm{F}=51,746$ dengan signifikansi sebesar $\mathrm{p}=0,000$ dengan ketentuan ( $\mathrm{p}<0,05)$, artinya varian pada skala Iklim Organisasi dan Work Family Balance tergolong linier.

Tabel 3. Hasil Uji Korelasi Antara Iklim Organisasi dengan Work Family Balance

\begin{tabular}{ccccc}
\hline $\mathbf{P}$ & $(\boldsymbol{\alpha})$ & Nilai Korelasi $(\mathbf{r})$ & R square & Kesimpulan \\
\hline 0,000 & 0.01 & 0,671 & 0,450 & $\begin{array}{c}\text { sig (2-tailed) } 0,000<0,01 \text { level of } \\
\text { significant }(\alpha), \text { berarti hipotesis } \\
\text { diterima. }\end{array}$ \\
\hline
\end{tabular}

Berdasarkan tabel di atas, maka diperoleh koefisien korelasi antara variabel Iklim Organisasi dengan Work Family Balance yaitu sebesar $\mathrm{r}=0,671$ dengan taraf signifikansi $\mathrm{p}=0,000$. Hal ini menunjukkan adanya korelasi yang kuat dan berarah positif atau searah antara kedua variabel tersebut, yang artinya jika semakin tinggi Iklim Organisasi, maka semakin tinggi Work Family Balance, sebaliknya jika semakin rendah Iklim Organisasi, maka semakin rendah Work Family Balance. Hal ini diperkuat dengan hasil uji signifikansi dengan bantuan IBM SPSS versi 21.0, didapatkan $\mathrm{p}=0,000<$ 0,01 level of significant $(\alpha)$, artinya hipotesis diterima, bahwa terdapat hubungan antara Iklim Organisasi dengan Work Family Balance pada Guru Wanita Bersertifikasi yang Sudah Berkeluarga di SMP N 2 Sawahlunto.

Tabel 4. Descriptive Statistic

\begin{tabular}{cccccc}
\hline Variabel & N & Mean & Std. Deviation & Minimum & Maximum \\
\hline Iklim Organisasi & 33 & 82,5455 & 13,67729 & 33 & 100 \\
Work Family Balance & 33 & 77,8788 & 11,17407 & 42 & 91 \\
\hline
\end{tabular}

Berdasarkan nilai mean hipotetik, maka dapat dilakukan pengelompokkan yang mengacu pada kriteria pengkategorisasian dengan tujuan menempatkan individu kedalam kelompok-kelompok yang terpisah secara berjenjang menurut suatu kontinum berdasarkan atribut yang diukur (Azwar, 2015) berdasarkan norma kategorisasi, diperoleh kategorisasi subjek penelitian pada variabel, Iklim Organisasi dan Work Family Balance sebagai berikut :

Tabel 5. Kategori Iklim Organisasi dengan Work Family Balance

\begin{tabular}{ccccc}
\hline Variabel & Skor & Jumlah & Persentase (\%) & Kategori \\
\hline \multirow{2}{*}{ Iklim Organisasi } & $33-68$ & 3 & $9 \%$ & Rendah \\
& $69-96$ & 25 & $76 \%$ & Sedang \\
Work Family Balance & $97-100$ & 5 & $15 \%$ & Tinggi \\
& $42-66$ & 3 & $9 \%$ & Rendah \\
& $67-89$ & 27 & $82 \%$ & Sedang \\
& $90-91$ & 3 & $9 \%$ & Tinggi \\
\hline
\end{tabular}

Berdasarkan tabel diatas, maka dapat diperoleh gambaran bahwa 9\% iklim organisasi pada kategori rendah, $76 \%$ iklim organisasi pada kategori sedang dan 15\% iklim organisasi pada kategori tinggi, sedangkan untuk variabel work family balance diperoleh gambaran bahwa sebesar $9 \%$ berada dalam kategori rendah, $82 \%$ dengan kategori sedang dan $9 \%$ memiliki kategori yang tinggi.

Besar sumbangan variabel iklim oraganisasi terhadap work family balance dapat ditentukan dengan menggunakan rumus koefisien determinan. Koefisien determinan adalah kuadrat dari koefisien korelasi yang dikali dengan $100 \%$. Adapun besar sumbangan efektif dari variabel iklim organisasi terhadap work family balance adalah sebesar $45 \%$ artinya iklim organisasi memiliki sumbangan sebesar $45 \%$ terhadap work family balance sedangkan 55\% dipengaruhi oleh faktor lain seperti 
dukungan keluarga, kepribadian, dukungan organisasi, orientasi kerja dan jenjang karir Guess (dalam Ayuningtyas \& Septarini, 2013).

\subsection{Pembahasan}

Berdasarkan hasil uji korelasi Product Moment (Pearson) yang dilakukan dengan bantuan IBM SPSS 21.0, dimana level of significant $(\alpha)$ 0,01 dan diperoleh nilai koefisien korelasi $\left(\mathrm{r}_{\mathrm{xy}}\right)=0,671$ dengan nilai (p) sig $=0,000$, karena nilai (p) sig $0,000<0,01$ maka hipotesis diterima. Hasil ini menunjukkan bahwa terdapat hubungan antara Iklim Organisasi dengan Work Family Balance pada Guru Wanita Bersertifikasi yang Sudah Berkeluarga di SMP N 2 Sawahlunto dengan arah positif. Artinya jika Iklim Organisasi tinggi, maka Work Family Balance pada Guru Wanita Bersertifikasi yang sudah Berkeluarga di SMP N 2 Sawahlunto juga akan tinggi, sebaliknya jika Iklim Organisasi rendah, maka Work Family Balance pada Guru Wanita Bersertifikasi yang sudah Berkeluarga di SMP N 2 Sawahlunto juga akan semakin rendah. Kondisi ini sesuai dengan yang dikemukakan oleh Brought dan Kalliath bahwa iklim kerja yang ramah keluarga memiliki pengaruh positif pada keduanya yaitu pada pekerjaan dan keluarga (Brought \& Kalliath, 2009). Taguiri \& Litwin (dalam Ardiansyah, 2017) menyatakan bahwa iklim organisasi sebagai suatu keadaan yang ada di lingkungan organisasi yang tercipta dalam suatu organisasi yang menggambarkan keadaan atau kondisi kerja di dalam organisasi. Adapun menurut Greenhause, Collins dan Shaw yaitu ada beberapa faktor yang dapat mempengaruhi work family balance yaitu dukungan organisasi, dukungan keluarga, kepribadian, orientasi kerja, jenjang karir dan salah satunya yaitu iklim organisasi. Seseorang dapat mencapai work family balance dengan mudah apabila bekerja pada lingkungan organisasi yang suportif terhadap keluarga (dalam Ayuningtyas \& Septarini, 2013).

Berdasarkan hasil pengolahan data mengenai sumbangan iklim organisasi terhadap work family balance, maka diperoleh nilai sumbangan efektif $(\mathrm{KP})=45 \%$, hal ini dapat diartikan bahwa iklim organisasi mampu memberikan konstribusi terhadap work family balance sebesar 45\% sedangkan 55\% sisanya dipengaruhi oleh faktor-faktor lain. Adapun faktor lain yang dapat mempengaruhi work family balance adalah dukungan keluarga, kepribadian, dukungan organisasi, orientasi kerja dan jenjang karir Guess (dalam Ayuningtyas \& Septarini, 2013).

\section{Kesimpulan}

Berdasarkan hasil pengumpulan data dan analisis data yang telah dilakukan oleh peneliti, maka dapat ditarik kesimpulan yang sekaligus merupakan jawaban dari tujuan penelitian adalah sebagai berikut : terdapat hubungan yang signifikan antara iklim organisasi dengan work family balance pada guru wanita bersertifikasi yang sudah berkeluarga di SMP N 2 Sawahlunto. Hubungan antara kedua variabel tersebut positif yang artinya jika iklim organisasi tinggi maka work family balance tinggi, sebaliknya jika iklim organisasi rendah maka work family balance rendah, hal ini berarti hipotesis diterima.

\section{Daftar Rujukan}

Ananda, M.R. (2013). Self Esteem Antara Ibu Rumah Tangga Yang Bekerja Dengan Yang Tidak Bekerja. Jurnal Psikologi. Vol. 1 No. 1.

Ardiansyah. (2017). Pengaruh Budaya Organisasi dan Iklim Organisasi Terhadap Loyalitas Kerja Karyawan. Jurnal. Universitas Riau.

Ayuningtyas \& Septarini. (2013). Hubungan Family Supportive Supervision Behaviors Dengan Work Family Balance Pada Wanita Yang Bekerja. Jurnal Psikologi Industri dan Organisasi Vol. 2 No. 1.

Azwar, Saifuddin. (2015). Metode Penelitian. Yogyakarta : Pustaka Pelajar

Brought, P \& Kalliath, T. (2009). “Work Family Balance: Theoritical and Empirical Advancements. Journal Organization Behavior.

Bulmer, M. (2015).The social basis of community care (Routledge revivals). New York: Routledge.

Handayani, A. (2013). Keseimbangan Kerja Keluarga pada Perempuan Bekerja: Tinjauan Teori Border. Buletin Psikologi Universitas Gajah Mada. Vol. 21 No. 2.

Handayani,dkk. (2018). Pengaruh Otonomi Terhadap Keseimbangan Kerja-Keluarga dengan Komitmen Peran sebagai Variabel Pemeditasi. Jurnal Psikologi. UNSYIAH 
Husni,Chairul. (2018). "Hubungan Iklim Organisasi terhadap Organizational Citizenship Behavior (OCB) pada Pegawai di Biro Organisasi Sekretariat Daerah Kantor Gubernur Sumatera Barat. Skripsi. UPI "YPTK" Padang.

Greenhaus, J. H., Ziegert, J. C., \& Allen, T. D. (2012). When Family-Supportive Supervision Matters: Relation Between Multiple Sources of Support and Work-Family Balance. Journal of Vocational Behavior, 266275.

Martha, A.D. (2014). "Hubungan Antara Iklim Organisasi dengan Organizational Citiznship Behavior (OCB) di Universitas Muhammadiyah Surakarta". Skripsi. Universitas Muhammadiyah Surakarta.

Maulana, A.M. (2017). Hubungan Kualitas Manajemen Waktu dan Work Family Balance Pada Pekerja Wanita. Jurnal. Universitas Negeri Semarang.

Novenia, Ika Z.R. (2017). Hubungan Antara Dukungan Sosial Suami dengan Work Family Balance pada Guru Wanita di SMA N Kabupaten Purworejo. Jurnal. Universitas Diponegoro.

Nurdin, D. (2015). Kompetensi Manajerial Kepala Sekolah dalam Membangun Iklim Sekolah dan Kepuasan Guru di Sekolah Dasar. Jurnal. Universitas Pendidikan Indonesia.

Phihatsanti,Kartika,S.D. (2010). Hubungan Antara Iklim Organisasi dan Organizational Citizenship Behavior (OCB) pada Guru SD NEGERI di Kecamatan Mojolaban Sukoharjo. Jurnal Psikologi. Universitas Diponegoro.

Prasetyawan, Ipung Alda. (2019). "Hubungan Iklim Organisasi dengan Work Family Balance pada Karyawan Wanita yang Sudah Berkeluarga". Skripsi. Universitas Islam Negeri Sunan Ampel Surabaya.

Priyatno, Duwi. (2018). SPSS Panduan Mudah Olah Data Bagi Mahasiswa \& Umum. Andi: Yogyakarta.

Sugiyono. (2016). Metode Penelitian Kuantitatif, Kulitatif dan R \& D. Alfabeta : Bandung.

Suryabrata, Sumadi. (2015). Metode Penelitian \& Research Methods. Jakarta: Raja Grafindo Persada.

Vitarini, A.N. (2009). "Hubungan Antara Konflik Peran Ganda Dengan Stress Kerja Pada Guru Wanita Sekolah Dasar Kecamatan Kebonarum Klaten”. Skripsi. Universitas Muhammadiyah Surakarta.

Wirawan. (2016). Budaya dan Organisasi. Jakarta : Salemba Empat

Wijayanto,A.Y, Nailul.F. (2018). Kerja digenggamanku Keluarga di Hatiku Interpretatif Phenomenological Analysis Tentang Work-Family Balance pada Ibu Bekerja. Jurnal. Universitas Diponegoro.

Yolanda, A.D. (2019). "Hubungan Family Suppertive Supervision Behaviors dengan Work Family Balance pada Dosen Wanita di STKIP PGRI Sumbar”. Skripsi. UPI "YPTK” Padang.

Kurniawan, H., \& Suryani, A. (2018). Hubungan Antara Keterlibatan Kerja dengan Kepuasan Kerja Karyawan PT. Dharmasraya Lestarindo Kab. Dharmasraya. Jurnal PSYCHE, 11(1), 345-353. 